\title{
Pengaruh Good Corporate Governance terhadap Manajemen Laba oleh CEO Baru pada Perusahaan Manufaktur
}

\author{
Ni Putu Widianjani ${ }^{1}$ \\ Fakultas Ekonomi dan Bisnis \\ Universitas Udayana, Indonesia \\ Email: npwidianjani@gmail.com
}

\author{
Gerianta Wirawan Yasa ${ }^{2}$ \\ Fakultas Ekonomi dan Bisnis \\ Universitas Udayana, Indonesia
}

\begin{abstract}
ABSTRAK
Pergantian CEO pada suatu perusahaan merupakan kegiatan yang pasti terjadi. Pada pergantian CEO banyak kemungkinan dapat terjadi yang salah satunya adalah praktik manajemen laba yang dilakukan oleh CEO baru. Praktik manajemen laba dapat dihindari dengan good corporate governance. Perusahaan manufaktur merupakan sektor pada BEI pada periode 2013-2017 yang dipilih sebagai populasi penelitian. Sampel yang diperoleh sebanyak 36 sampel kemudian akan diolah dengan menggunakan regresi linear berganda. Sampel ini didapatkan melalui seleksi kriteria yaitu dengan teknik purposive sampling. Hasil yang didapatkan yaitu good corporate governance memiliki pengaruh yang negatif pada manajemen laba.
\end{abstract}

Kata Kunci: Good Corporate Governance; Manajemen Laba; Pergantian CEO.

Effect of Good Corporate Governance on Earnings Management by New CEOs on Manufacturing Companies$$
\text { ABSTRACT }
$$

CEO turnover in a company is a certain activity. At the turn of the CEO many possibilities can occur, one of which is earnings management practices carried out by the new CEO. Earnings management practices can be avoided with good corporate governance. Manufacturing companies were the sectors of the IDX in the 2013-2017 period selected as the study population. Samples obtained as many as 36 samples will then be processed using multiple linear regression. This sample was obtained through selection criteria, namely by purposive sampling technique. The results obtained are good corporate governance has a negative effect on earnings management.

Keywords: Good Corporate Governance; Earnings Management; CEO Turnover.
\end{abstract}

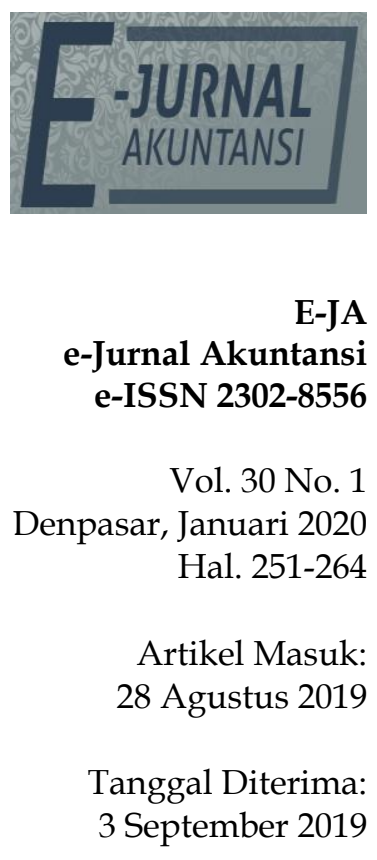

3 September 2019 


\section{PENDAHULUAN}

Perusahaan harus menyajikan laporan keuangan yang menggambarkan keadaan perusahaan yang sesungguhnya. Hal ini terkait dengan digunakannya laporan keuangan sebagai dasar pengambilan keputusan. Persusahaan kebanyakan menggunakan dasar akrual dalam penyajian laporan keuangan. daasar akrual dipilih dengan alasan bahwa laporan keuangan yang dihasilkan dengan metode akrual dapat menggambarkan secara riil keadaan keuangan dari perusahaan. Dasar akrual ini memiliki kekurangan yaitu penyusunan laporan keuangan dengan dasar akrual memiliki kemungkinan dimodifikasi oleh penyusun dan menyesuaikan laba yang diinginkan. Modifikasi pada laba ini merupakan manajemen laba dimana manajemen secara sengaja memilih metode akuntansi karena memiliki tujuann tertentu.

Definisi lain dari manajemen laba yaitu dari beberapa kebijakan akuntansi yang terdapat pada standar akuntansi, manajemen secara sengaja memilih salah satu kebijakan yang dapat memaksimalkan kepentingannya(Putra et al., 2014). Asimetri informasi merupakan salah satu masalah yang sering muncul ketika proses penyajian laporan keuangan. asimetri informasi terjadi antara manajemen dengan pemegang saham. Manajemen sebagai bagian internal perusahaan, cenderung mudah dalam mendapatkan informasi mengenai perusahaan secara detail dan hal tersebut sering dimanfaatkan oleh manajemen untuk kepentingan pribadi. Selain itu kebebasan dalam memilih kebijakan akuntansi juga dapat membantu manajemen dalam menjalankan kepentingan pribadinya (Perwitasari, 2014).

CEO baru akan menurunkan laba (income decreasing) pada tahun pertama ia menjabat. Penurunan laba dilakukan dengan menangguhkan laba periode sekarang ke periode berikutnya. Dampak manajemen laba pada tahun pergantian akan berbalik pada periode berikutnya, sehingga akan berdampak positif pada kompensasi yang diperoleh (Narolita \& Krisnadewi, 2016). Penelitian yang dilakukan Jayanthi dan Putra et al., (2014) sertaSirait \& Yasa (2015) mendapatkan temuan adanya manajemen laba yang dilakukan oleh CEO baru. Manajemen laba yang dilakukan sesuai dengan hasil penelitian yaitu income decreasing.

Manajemen laba (earnings management) bukanlah hal yang baru dilakukan oleh manajemen perusahaan. Praktik manajemen laba sudah banyak diterapkan oleh manajemen yang kemudian terlihat dari munculnya kasus mengenai pelaporan akuntansi. Di Indinesia salah satu kasusnya adalah PT. Toshiba Corporation. Fenomena manjemen laba yang terjadi dalam perusahaan manufaktur yaitu Kasus PT Inovisi Infracom (INVS) pada tahun 2015.

Menurut Watts \& Zimmerman (1990) diterapkannya GCG oleh perusahaan dengan harapan dapat mengurangi untuk mengurangi adanya praktik manajemen laba. Independensi merupakan kunci utama yang harus dimiliki oleh komite audit. Tanggung jawabnya dalam mengawasi manajemen memerlukan independensi agar tidak mudah diintervensi oleh pihak lain. Komite audit dengan independensi tinggi cenderung memberikan kepercayaan bagi pihak ekternal mengenai kualitas laporan keuangan yang dihasilkan oleh perusahaan. 
Sirait \& Yasa (2015) serta Nabila dan Daljono (2013) menemukan dalam penelitiannya bahwa terdapat hubungan negative antara hubungan CEO baru pada manajemen laba. Hal ini berarti bahwa ukuran komite audit dan aktivitasnya belum mampu mengurangi manajemen laba secara efektif berbeda dengan Fathoni \& Ancella (2013) menyatakan bahwa aktivitas komite audit berpengaruh negatif terhadap manajemen laba.

Penelitian ini berusaha memberikan bukti indikasi manajemen laba ketika terjadi pergantian CEO. Penelitian ini menggunakan periode penelitian tahun terbaru karena penelitian sebelumnya menggunakan periode yang lama sehingga dengan menggunakan periode tahun terbaru maka dapat mengetahui perkembangan terbaru mengenai penerapan GCGsaat ini.

penelitian yang dilakukan oleh Firnanti (2017)mengungkapkan konflik keagenan pada hubungan antara agent dengan principal sangat mungkin terjadi karena agent memiliki informasi lebih yang kemungkinan digunakan untuk menguntungkan dirinya sendiri. Hal tersebut tidak sesuai dengan tujuan principal ketika menyerahkan wewenang kepada agent dalam menjalankan perusahaan.

Teori keagenan digunakan sebagai dasar untuk memahami goodcorporate governance. Berlandaskan ketiga asumsi tersebut manajer akan bertindak opportunistic, yaitu mengutamakan kepentingan pribadinya. Di satu sisi, manajer cenderung berusaha keras memaksimumkan utilitasnya sendiri. Namun di sisi lain, untuk memaksimalkan utilitas pemilik manajer dituntut untuk bekerja keras. CEO bertindak sebagai agen dan pemegang saham bertindak sebagai principal pada perusahaan yang modalnya terdiri atas saham. Dengan lebih banyaknya informasi yang dimiliki oleh agent, menjadikan agent termotivasi untuk memenuhi kepentingannya secara sepihak, misalnya CEO baru merekayasa kinerjanya untuk dapat mempertahankan posisinya atau CEO lama merekayasa kinerjanya untuk mendapatkan bonus yang lebih maksimal pada akhir masa jabatannya. Penelitian yang dilakukan Bengtsson et al., (2006), Hui (2012) membuktikan bahwa manajemen laba terjadi dilakukan oleh CEO baru.

Scott (2014) juga mengemukakan beberapa motivasi terjadinya manajemen laba, yaitu : Bonus Purpose, The debt covenant hypothesis, Initital Public Offering (IPO), Pergantian CEO, Taxation Motivations, dan Political Motivations dengan Increasing income, Income minimization, Taking a bath disebut juga big baths, Income maximization, Income smoothing merupakan pola manajemen laba

Proporsi komisaris independen pada jumlah seluruh komisaris yang semakin besar, menyebabkan peran dewan komisaris sebagai mekanisme kontrol atas tindakan direksi semakin baik dilakukan (Puteri, 2013). Menurut Komite Nasional Kebijakan Corporate Governance mengenai Komite Audit adalah: "Suatu komite yang beranggotakan satu atau lebih anggota dewan komisaris dan dapat meminta kalangan luar dengan berbagai keahlian, pengalaman, dan kualitas lain yang dibutuhkan untuk mencapai tujuan Komite Audit." 


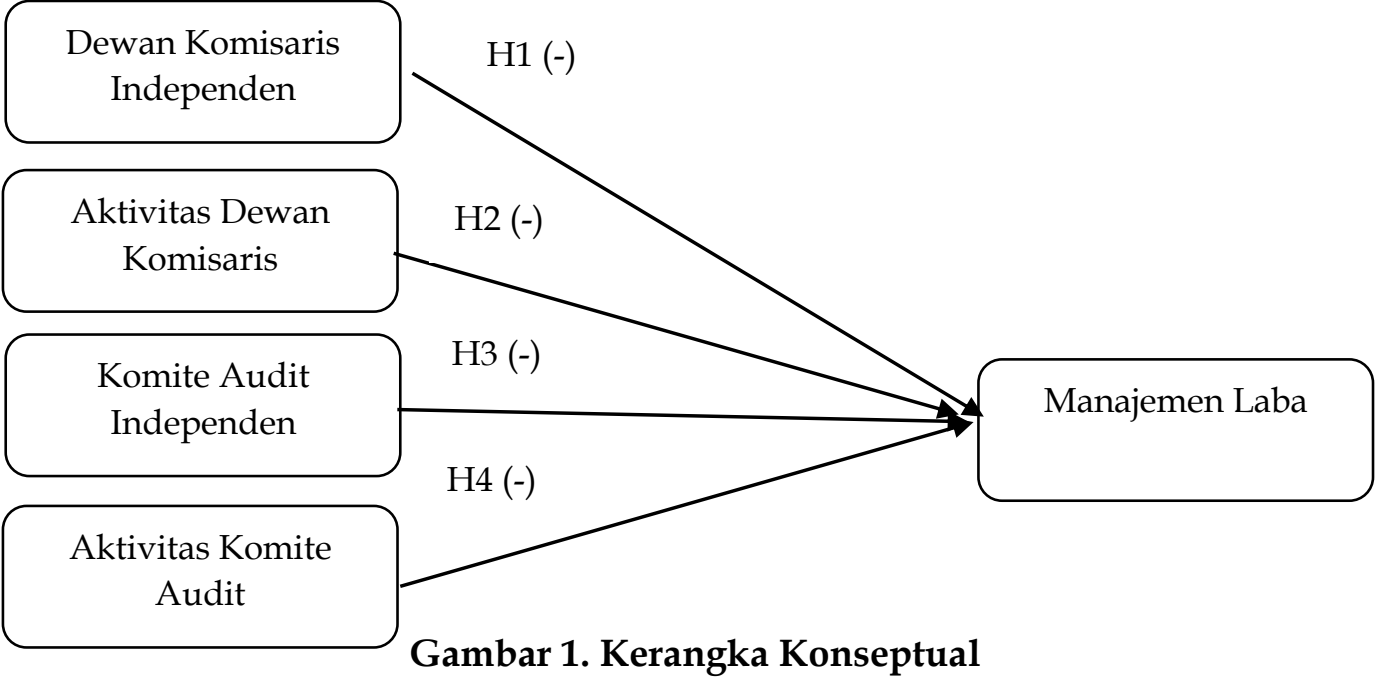

Sumber: Data Penelitian, 2019

\section{METODE PENELITIAN}

Penelitian ini dilakukan di perusahaan manufaktur yang terdaftar di Bursa Efek Indonesia periode tahun 2013-2017 dengan mengakses data melalui situs www.idx.co.id. Objek penelitian merupakan suatu sifat objek yang ditetapkan oleh peneliti untuk dipelajari dan kemudian memperoleh kesimpulan (Sugiyono, 2017). Objek pada penelitian ini adalahGood Corporate Governance (dewan komisaris independen, aktivitas dewan komisaris, komite audit independen, dan aktivitas komite audit), manajemen laba, dan CEO baru pada perusahaan manufaktur di Bursa Efek Indonesia periode 2013-2017.

Penelitian ini menggunakan pendekatan kuantitatif berbentuk asosiatif. Pendekatan kuantitatif merupakan penelitian yang lebih menekankan pada pengujian teori-teori melalui variabel-variabel penelitian dengan angka dan melakukan analisis data dengan prosedur statistik (Indriantoro \& Supomo., 2014). Menurut Sugiyono (2017) penelitian asosiatif merupakan penelitian yang bertujuan untuk mengetahui hubungan antara dua variabel atau lebih.Hal ini sesuai dengan tujuan penelitian yaitu untukmenganalisis GoodCorporate Governance yaitu dewan komisaris independen, aktivitas dewan komisaris, komite audit independen, dan aktivitas komite auditterhadap manajemen laba oleh CEO Barustudi kasus pada perusahaan manufaktur yang terdaftar di Bursa Efek Indonesia periode2013-2017. Teknik analisis yangdigunakan untuk menguji hipotesis dalam penelitian ini adalah uji statistik deskriptif, uji asumsi klasik dan uji analisis linear berganda. Hasil analisis kemudian diinterprestasikan untuk menjawab permasalahan. Langkah terakhir penelitian ini adalah membuat suatu simpulan dan saran penelitian.Desain penelitian dalam penelitian ini dapat digambarkan pada Gambar 2.

Sugiyono (2017)menyebutkan bahwa variabel merupakan hal yang berbentuk apa saja dan telah ditetapkan oleh peneliti untuk dipelajari sehingga dapat diperoleh informasi dan ditarik kesimpulan mengenai hal tersebut. Penelitian ini menggunakan tiga buah variabel, yaitu: 1) Variabel bebas (independen), yaitu variabel yang menjadi sebab perubahan atau yang mempengaruhi variabel terikat (dependen) (Sugiyono, 2017). 


\section{Pengaruh GCG Terhadap Manajemen Laba oleh CEO Baru}

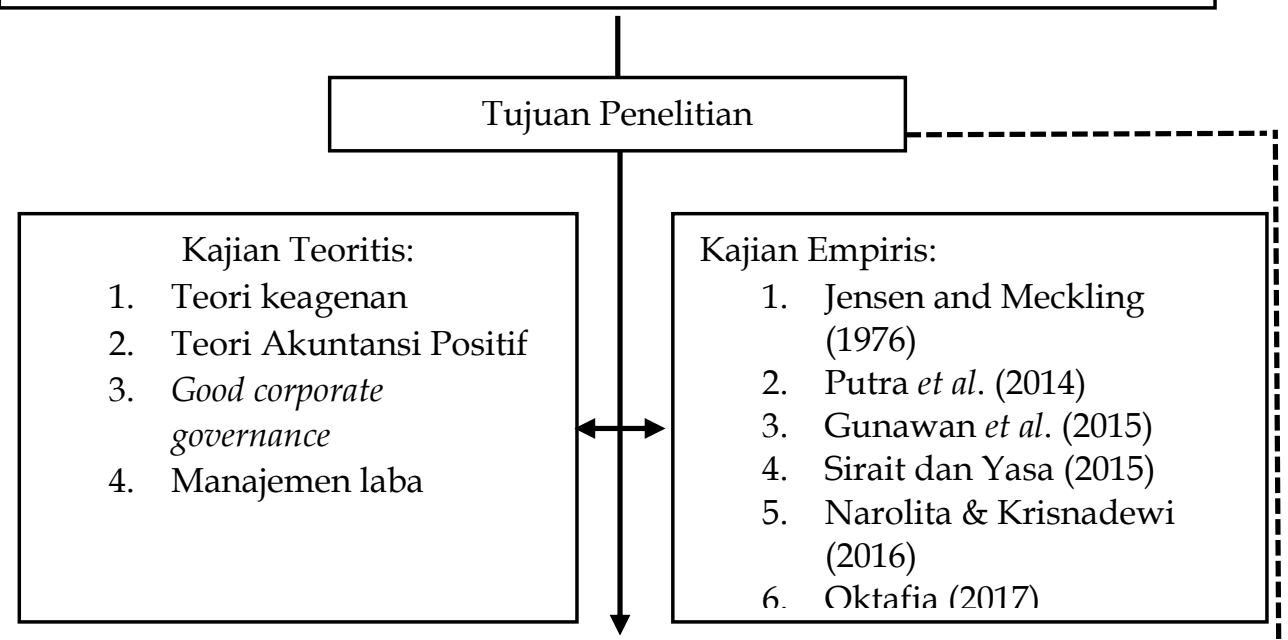

Variabel Penelitian:

Manajemen Laba, Good Corporate Governance, dan CEO Baru

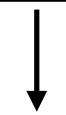

Hipotesis Penelitian:

$\mathrm{H}_{1}$ : Dewan komisaris independen berpengaruh negatif terhadap manajemen laba.

$\mathrm{H}_{2}$ : Aktivitas dewan komisaris berpengaruh negatif terhadap manajemen laba

$\mathrm{H}_{3}$ : Komite audit independen berpengaruh negatif terhadap manajemen laba

Sumber: Data Penelitian, 2019

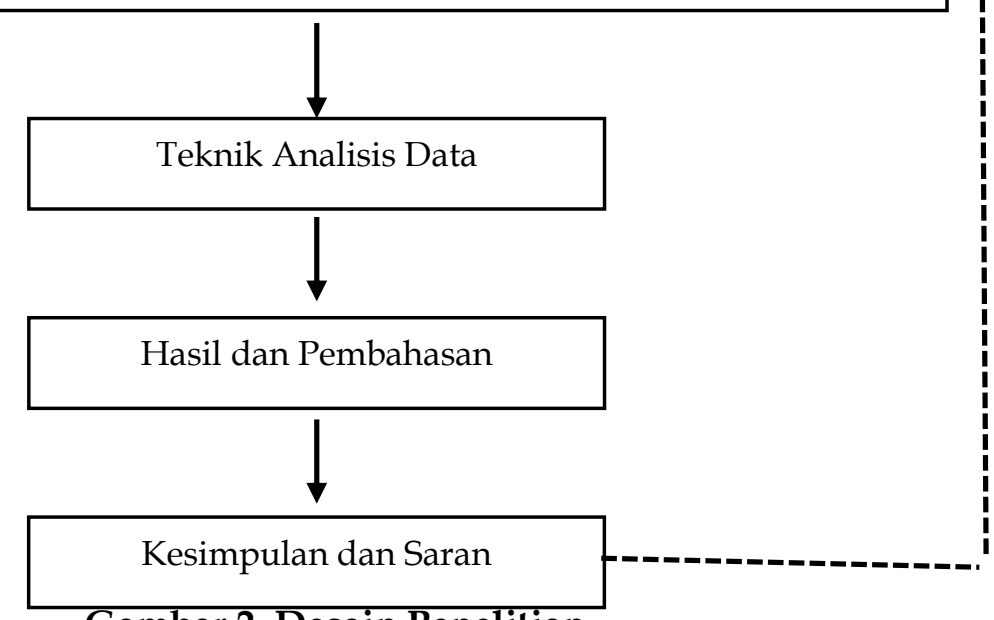

Gambar 2. Desain Penelitian 
Variabel bebas dalam penelitian ini adalah good corporate governance yaitu dewan komisaris independen, aktivitas dewan komisaris, komite audit independen, dan aktivitas komite audit, 2) Variabel terikat (dependen), yaitu variabel yang terkena akibat atau yang dipengaruhi karena adanya variabel bebas (independen) (Sugiyono, 2017). Variabel terikat dalam penelitian ini adalah manajemen laba pada awal masa jabatan CEO baru.

Variabel dependen penelitian ini adalah variabel manajemen laba. Manajemen laba adalah suatu kondisi dimana manajemen melakukan intervensi dalam proses penyusunan laporan keuangan yang diproksikan dengan discretionary accrual (DA), yang diukur dengan menggunakan model Modified Jones Model. Pemilihan model Modified Jones Model karena model ini dianggap memiliki kemampuan terbaik dalam menjelaskanmanajemen laba sesuai dengan penelitian yang dilakukan oleh (Dechowet al., 1998).

Persamaan model Jones modifikasian adalah sebagai berikut:

TACit $=$ Nit - CFOit

Nilai total accrual (TA) diestimasi dengan persamaan regresi linear berganda yang berbasis ordinary least square (OLS) sebagai berikut:

TACit/Ait-1= $\beta 1(1 /$ Ait-1) $+\beta 2(\Delta$ REVt $/$ Ait-1- $\Delta$ RECt $/$ Ait-1) $+\beta 3($ PPEt/Ait-1) + e....(2)

Dengan menggunakan koefisien regresi di atas nilai nondiscretionary accruals (NDA) dapat dihitung dengan rumus:

NDAit $==\beta 1(1 /$ Ait -1$)+\beta 2(\Delta \mathrm{REVt} /$ Ait-1- $\Delta$ RECt $/$ Ait-1) $+\beta 3($ PPEt $/$ Ait -1$)$

Selanjutnya Discretionary Accrual (DA) dapat dihitung sebagai berikut:

DAit $=$ TAit / Ait-1 - NDAit.

Keterangan:

TACit $=\quad$ Total accruals perusahaan $\mathrm{i}$ pada periode $\mathrm{t}$

Nit $=\quad$ Laba bersih perusahaan i pada periode $\mathrm{t}$

CFOit $=\quad$ Aliran kas dari aktivitas operasi perusahaan i pada periode $\mathrm{t}$

Ait-1 $=\quad$ Total aset perusahaan i pada tahun $\mathrm{t}-1$

$\triangle \mathrm{REVt}=\quad$ Perubahan pendapatan perusahaan i dari tahun $\mathrm{t}-1$ ke tahun $\mathrm{t}$

$\triangle \mathrm{REC} \mathrm{t}=\quad$ Perubahan piutang perusahaan $\mathrm{i}$ dari tahun $\mathrm{t}-1$ ke tahun $\mathrm{t}$

PPEt $=$ Aset tetap perusahaan tahun $\mathrm{t}$

DAit $=\quad$ Discretionary Accruals perusahaan i pada periode ke $\mathrm{t}$

NDAit $=\quad$ Non Discretionary Accruals perusahaan i pada periode ke $\mathrm{t}$

$\beta=\quad$ Koefisien regresi

$\mathrm{e}=\quad$ error

Variabel independen Good Corporate Governancediproksikan dengan dewan komisaris independen, aktivitas dewan komisaris, komite audit independen, dan aktivitas komite audit. 1) Komisaris Independen adalah anggota dewan komisaris yang tidak terafiliasi dengan manajemen, anggota dewan komisaris lainnya dan pemegang saham pengendali, serta bebas dari hubungan bisnis atau hubungan lainnya yang dapat mempengaruhi kemampuannya untuk bertindak independen dan bertindak semata-mata demi kepentingan perusahaan. Untuk variabel dewan komisaris independen diukur dengan persentase jumlah komisaris independen terhadap jumlah seluruh dewan komisaris,2) Aktivitas dewan komisaris diwujudkan melalui frekuensi pertemuan dalam satu tahun. Variabel ini diukur secara numeral, yaitu dilihat dari jumlah nominal pertemuan yang dilakukan oleh dewan komisaris selama 
satu tahun berjalan. Data mengenai dewan komisaris diperoleh dari laporan tahunan perusahaan, 3) Komite audit independen diukur dengan persentase jumlah komisaris independen terhadap jumlah seluruh dewan komisaris.

Aktivitas komite audit diukur secara numeral, yaitu dilihat dari jumlah nominal pertemuan yang dilakukan oleh komite audi dalam tahun berjalan. Data mengenai komite audit diperoleh dari laporan tahunan perusahaan.Penelitian ini menggunakan sampel perusahaan manufaktur yang terdaftar di BEI periode 2013-2017 yang dipilih melalui teknik purposive sampling

Teknik dalam mengambil sampel yaitu dengan teknik nonprobabilitas dengan metode purposive sampling dengan kriteria yang ditentukan sebagai berikut 1) Perusahaan manufaktur yang terdaftar di Bursa Efek Indonesia selama periode 2013-2017yang melakukan pergantian CEO, 2) Perusahaan manufaktur yang mempublikasikan laporan keuangan secara lengkap pada periode 2013$2017,3)$ Laporan keuangan tahunan yang diterbitkan dalam mata uang rupiah, 4) Perusahaan yang menyediakan data mengenai struktur dan aktivitas dewan komisaris serta komite audit secara lengkapselama periode 2013-2017.

Metode pengumpulan data yang digunakan dalam penelitian ini adalah metode observasi nonpartisipan. Data yang dikumpulkan melalui observasi nonpartisipan dengan cara pengamatan terhadap dokumen-dokumen atau catatan yang dihasilkan oleh pihak lain terkait penelitian ini.Populasi penelitian berjumlah 138 Perusahaan yang terdiri dari seluruh perusahaan manufaktur dengan periode terdaftarnya di BEI selama 2013-2017. Berdasarkan metode purposive sampling 36 perusahaan memenuhi kriteria dan dijadikan sampel. Data laporan keuangan yang digunakan adalah data periode 2013 - 2017. Tabel 4.1 menyajikan proses seleksi sampel.Populasi adalah wilayah generalisasi yang terdiri atas obyek atau subyek yang mempunyai kualitas dan karakteristik tertentu yang ditetapkan oleh peneliti untuk mempelajari dan kemudian ditarik kesimpuannya (Sugiyono, 2017). Populasi dalam penelitian ini adalah seluruh perusahaan manufaktur yang terdaftar di BEI periode 2013-2017.

Sampel adalah bagian dari jumlah dan karakteristik yang dimiliki oleh populasi (Sugiyono, 2017). Sampel yang digunakan dalam penelitian ini adalah perusahaan manufaktur yang terdaftar di BEI periode 2013-2017 yang dipilih melalui teknik purposive sampling.

Pengambilan sampel dilakukan dengan teknik nonprobabilitas dengan metode purposive sampling dengan kriteria yang ditentukan sebagai berikut, 1)Perusahaan manufaktur yang terdaftar di Bursa Efek Indonesia selama periode 20132017yang melakukan pergantian CEO, 2)Perusahaan manufaktur yang mempublikasikan laporan keuangan secara lengkap pada periode 2013-2017, 3)Laporan keuangan tahunan yang diterbitkan dalam mata uang rupiah, 4)Perusahaan yang menyediakan data mengenai struktur dan aktivitas dewan komisaris serta komite audit secara lengkapselama periode 2013-2017.

Metode pengumpulan data yang digunakan dalam penelitian ini adalah metode observasi nonpartisipan. Metode observasi nonpartisipan ini berarti peneliti dapat melakukan observasi sebagai pengumpul data tanpa harus ikut terlibat didalamnya, peneliti hanya sebagai pengamat yang independen (Sugiyono, 2017). Data yang dikumpulkan melalui observasi nonpartisipan dengan cara pengamatan terhadap dokumen-dokumen atau catatan yang 
dihasilkan oleh pihak lain terkait penelitian ini.Jenis data dalam penelitian ini adalah data kuantitatif. Data kuantitatif adalah data yang berbentuk angkaangka. Data kuantitatif yang digunakan dalam penelitian ini adalah angka-angka dalam laporan keuangan dan laporan tahunan perusahaan manufaktur tahun 2013-2017.Penelitian ini menggunakan data sekunder berupa data historis yang diperoleh dari berbagai sumber dan literatur melalui media perantara, misalnya melalui peneliti lain atau melalui dokumen (Sugiyono, 2017). Data sekunder terdiri dari literatur, buku referensi, data laporan keuangan, dan informasi kinerja keuangan perusahaan sampel yang diperoleh dari website BEI (www.idx.co.id).

\section{HASIL DAN PEMBAHASAN}

Populasi penelitian berjumlah 138 Perusahaan yang terdiri dari seluruh perusahaan manufaktur dengan periode terdaftarnya di BEI selama 2013-2017. Berdasarkan metode purposive sampling 36 perusahaan memenuhi kriteria dan dijadikan sampel. Data laporan keuangan yang digunakan adalah data periode 2013 - 2017. Tabel 1. menyajikan proses seleksi sampel.

\section{Tabel 1. Hasil Seleksi Pemilihan Sampel}

\begin{tabular}{lll}
\hline No & Kriteria & $\begin{array}{l}\text { Jumlah } \\
\text { Perusahaan }\end{array}$ \\
\hline 1. & $\begin{array}{l}\text { Merupakan perusahaan manufaktur yang terdaftar di BEI } \\
\text { periode 2013-2017 }\end{array}$ & 138 \\
2. & $\begin{array}{l}\text { Perusahaan manufaktur yang terdaftar di Bursa Efek Indonesia } \\
\text { selama periode 2013-2017yang tidak melakukan pergantian }\end{array}$ & $(92)$ \\
& CEO & \\
3. & $\begin{array}{l}\text { Laporan keuangan dan laporan tahunan tidak tersedia secara } \\
\text { lengkap selama lima tahun berturut-turut hingga digantinya }\end{array}$ & \\
& $\begin{array}{l}\text { CEO } \\
\text { Laporan keuangan tahunan yang tidak diterbitkan dalam mata }\end{array}$ & $(6)$ \\
uang rupiah & $\begin{array}{l}\text { Data yang tidak lengkap mengenai good corporate governance } \\
\text { perusahaan meliputi dewan komisaris dan komite audit. }\end{array}$ & (2) \\
Jumlah sampel penelitian & 36 \\
\hline
\end{tabular}
Sumber: Data Penelitian, 2019

Statistik deskriptif memberikan gambaran atau deskripsi tentang suatu data yang dilihat melalui nilai rata-rata (mean), standar deviasi, maksimum, minimum. Hasil analisis deskriptif data dapat dilihat pada tabel 2.

Tabel 2. Hasil Statistik Deskriptif

\begin{tabular}{llllll} 
& $\mathrm{N}$ & Minimum & Maksimum & Rata-rata & Deviasi Standar \\
\hline BCIND & 36 & 0,286 & 0,667 & 0,436 & 0,127 \\
BCMEET & 36 & 2 & 16 & 7,440 & 4,225 \\
ACIND & 36 & 0,333 & 1,000 & 0,617 & 0,262 \\
ACMEET & 36 & 4 & 31 & 8,640 & 5,525 \\
$\mid$ DA | & 36 & $-0,265$ & 0,100 & $-0,069$ & 0,073 \\
Valid N (listwise) & 36 & & & &
\end{tabular}

Sumber: Data Penelitian, 2019 
Statistik deskriptif menjelaskan nilai minimum,maksimum,rata-rata dan sebaran data. Manajemen laba dengan proksi DA memiliki nilai min, maks, dan mean sebesar 0,265; 0,100; dan -0,069. Ketiga hasil ini memberikan gambaran bahwa perusahaan cenderung melakukan manajemen laba yang rendah. BCIND memiliki nilai min, maks, dan mean sebesar 0,286; 0,667; dan 0,436.

\section{Tabel 3.Hasil Uji Normalitas}

One-Sample Kolmogorov-Smirnov Test

\begin{tabular}{lll} 
& & Unstandardized Residual \\
\hline Normal Parameters $\mathrm{a}, \mathrm{b}$ & & 36 \\
& Mean & 0,000 \\
Most Extreme Differences & Std. Deviation & 0,026 \\
& Absolute & 0,102 \\
& Positive & 0,102 \\
Test Statistic & Negative & $-0,055$ \\
Asymp. Sig. (2-tailed) & & 0,102 \\
\hline
\end{tabular}

Sumber: Data Penelitian, 2019

Ketiga hasil ini memberikan gambaran bahwa dewan komisaris perusahaan cenderung independen. BCMEET memiliki nilai nilai min, maks, dan mean sebesar 2; 16; dan 7,440. Ketiga hasil ini memberikan gambaran bahwa dewan komisaris perusahaan cenderung jarang dalam melakukan rapat dalam satu tahun. ACIND memiliki nilai min, maks, dan mean sebesar 0,333; 1,000; dan 0,617 . Ketiga hasil ini memberikan gambaran bahwa komite audit dalam perusahaan yang diteliti cenderung independen. ACMEET memiliki nilai min, maks, dan mean sebesar 4; 31; dan 8,640. Ketiga hasil ini memberikan gambaran bahwa komite audit pada perusahaan yang diteliti cenderung jarang dalam melakukan rapat dalam satu tahun.

Dari uji normalitas yang dilakuka $\mathrm{n}$ dengan SPSS didapatkan hasil nilai Asym. Sig. melebihi 0,05. Hasil ini memiliki arti bahwa distribusi yang digunakan untuk penelitian berdistribusi normal.

Uji Heteroskedastisitas bertujuan menguji apakah dalam model regresi terjadi ketidaksamaan variance dari residual satu pengamatan ke pengamatan yang lain.

Pada penelitian ini digunakan uji Glejser untuk mendeteksi ada atau tidaknya heteroskedastisitas.Jika tingkat signifikansi masing-masing variabel bebas lebih besar dari 0,05 dan variabel bebas yang dianalisis tidak mempunyai pengaruh yang signifikan terhadap absolute residual, maka dapat disimpulkan bahwa model regresi yang dianalisis tidak terdapat gejala heteroskedastisitas.

Dilakukan uji heteroskedastisitas pada data penelitian yang kemudian didapatkan hasil yaitu nilai sig. yang didapatkan telah melebihi 0,05. Hasil ini berarti syarat agar terbebas dari gejala heteroskedastisitas terpenuhi. 
Tabel 4.Uji Heteroskedastisitas

\begin{tabular}{lllllll}
\hline \multicolumn{2}{c}{} & \multicolumn{2}{l}{$\begin{array}{l}\text { Unstandardized } \\
\text { Coefficients }\end{array}$} & \multicolumn{2}{l}{$\begin{array}{l}\text { Standardized } \\
\text { Coefficients }\end{array}$} \\
Model & & B & Std. Error & Beta & $\mathrm{t}$ & Sig. \\
\hline 1 & (Constant) & 0,036 & 0,009 & & 3,770 & 0,001 \\
& BCIND & $-0,034$ & 0,024 & $-0,266$ & $-1,423$ & 0,165 \\
& BCMEET & $-0,002$ & 0,001 & $-0,507$ & $-1,924$ & 0,064 \\
& ACIND & 0,027 & 0,016 & 0,434 & 1,706 & 0,098 \\
& ACMEET & 0,000 & 0,001 & $-0,123$ & $-0,501$ & 0,620 \\
\hline
\end{tabular}

Sumber: Data Penelitian, 2019

Setelah dilakukan uji multikolinearitas, hasil yang didapatkan adalah model regresi terbebas dari masalah multikolinearitas. Bebasnya dari gejala multikolinearitas karena telah memenuhi syarat yaitu nilai tolerance yang melebihi 10 persen serta VIF yang tidak lebih dari 10.

Tabel 5. Uji Multikolinieritas

\begin{tabular}{llll}
\hline \multirow{2}{*}{ Model } & & \multicolumn{2}{l}{ Collinearity Statistics } \\
\hline 1 & BCIND & Tolerance & VIF \\
& BCMEET & 0,713 & 1,402 \\
& ACIND & 0,360 & 2,779 \\
& ACMEET & 0,386 & 2,592 \\
\end{tabular}

Sumber: Data Penelitian, 2019

Dilakukan uji koefisien determinasi pada variabel untuk melihat seberapa banyak variabel bebas yang telah dipilih dapat menjelaskan variabel tetap. Dari hasil yang didapatkan yaitu $86,1 \%$ dari variabel tetap dijelaskan oleh variabel bebas yang telah dipilih dan sisanya dijelaskan oleh faktor lain diluar penelitian yaitu sebesar $13,9 \%$.

\section{Tabel 6. Hasil Uji Koefisien Determinasi}

\begin{tabular}{lllll}
\hline Model & $\mathrm{R}$ & $\mathrm{R}$ Square & Adjusted R Square & Std. Error of the Estimate \\
\hline 1 & $0,936^{\mathrm{a}}$ & 0,877 & 0,861 & 0,027 \\
\hline
\end{tabular}

Sumber: Data Penelitian, 2019

Berdasarkan tabel 4.7 dapat dilihat bahwa besar signifikansi F 0,000 lebih kecil dibandingkan dengan 0,05 $(0,000<0,05)$ Artinya model layak untuk digunakan

Uji hipotesis (Uji t)menunjukkan seberapa jauh pengaruh satu variabel bebas secara individual dapat menjelaskan variasi variabel terikat. Dalam penelitian ini menggunakan analisis regresi linear berganda.

Tabel 7. Hasil Uji Kelayakan Model (Uji F)

\begin{tabular}{|c|c|c|c|c|c|c|}
\hline & del & Sum of Squares & Df & Mean Square & $\mathrm{F}$ & Sig. \\
\hline \multirow[t]{3}{*}{1} & Regression & 0,164 & 4 & 0,041 & 55,057 & $0,000^{\mathrm{b}}$ \\
\hline & Residual & 0,023 & 31 & 0,001 & & \\
\hline & Total & 0,187 & 35 & & & \\
\hline
\end{tabular}

Sumber: Data Penelitian,

Pengujian pada hipotesis pertama diperoleh hasil bahwa ditemukannya pengaruh negative antara hubungan BCIND pada manajemen laba. Dari uji hipoteisis dihasilkan nilai koefisien yaitu $-0,117$. Nilai ni memberikan informasi mengenai arah dari hubungan antara variabel yang diteliti. Meningkatnya BCIND akan berdampak pada menurunnya manajemen laba. Tingkat 
signifikansi yang didapatkan adalah sebesar 0,01 maka $\mathrm{H}_{0}$ ditolak. Penelitian sebelumnya yang mendapatkan hasil yang sama yaitu Pradito (2015), Sirait \& Yasa (2015), Nabila \& Daljono (2013) serta Afnan (2014). Pengawasan terhadap aktivitas manajemen akan lebih ketat ketika dewan komisaris independen bertambah. Dengan ketatnya pengawasan yang dilakukan maka kesempatan bagi manajemen untuk melakukan praktik manajemen laba akan semakin berkurang.

Tabel 8. Uji Hipotesis

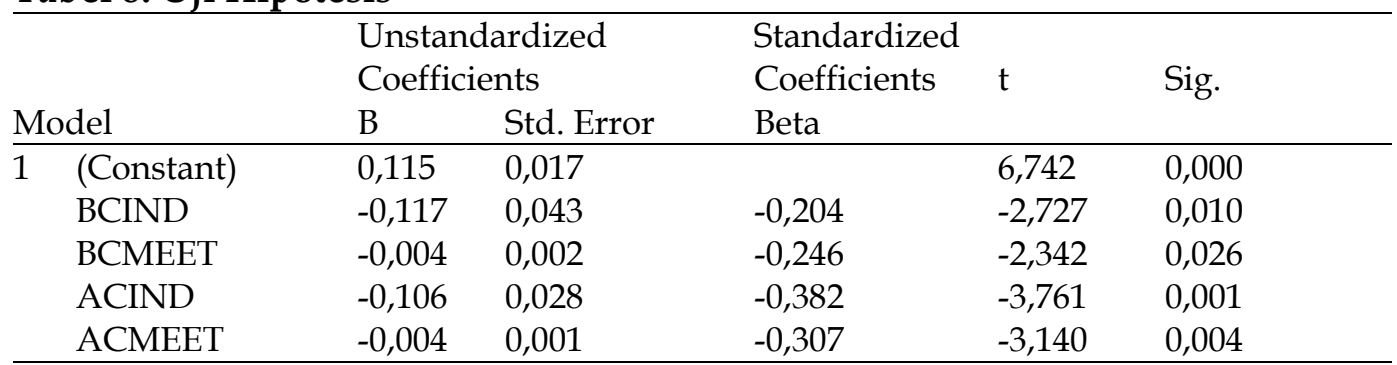

Sumber: Data Penelitian

$|\mathrm{DA}|=0,115-0,117 \mathrm{BCIND}-0,004 \mathrm{BCMEET}-0,106 \mathrm{ACIND}-0,004$ ACMEET+ 0,017 .

Pengujian pada hipotesis kedua diperoleh hasil bahwa ditemukannya pengaruh negative antara hubunganBCMEET pada manajemen laba. Dari uji hipotesis dihasilkan nilai koefisien yaitu $-0,004$. Nilai ini memberikan informasi mengenai arah dari hubungan antara variabel yang diteliti. Meningkatnya BCMEET akan berdampak pada menurunnya manajemen laba. Dengan tingkat signifikansi 0,026 menandakan $\mathrm{H}_{2}$ diterima. Penelitian sebelumnya yang yang mendapatkan hasil yang sama yaitu Fathoni \& Ancella (2013), Sirait \& Yasa (2015) dan Suripto (2012). Tanggung jawab yang dimiliki oleh dewan komisaris dilakukan salah satunya dengan mengadakan rapat. Ketika rapat dilakukan secara rutin selama satu periode maka pengawasan terhadap laporan keuangan akan lebih terpantau dengan baik. Dengan lebih sering mengadakan rapat maka pengawasan terhadap laporan keuangan akan lebih terjaga dan mendetail.

Pengujian pada hipotesis ketiga diperoleh hasil bahwa ditemukannya pengaruh negative antara hubunganACIND pada manajemen laba. Dari uji hipotesis dihasilkan nilai koefisien yaitu $-0,106$. Nilai ni memberikan informasi mengenai arah dari hubungan antara variabel yang diteliti. Meningkatnya ACIND akan berdampak pada menurunnya manajemen laba. Tingkat signifikansi yang didapatkan adalah sebesar 0,001maka $\mathrm{H}_{0}$ ditolak. Penelitian sebelumnya yang yang mendapatkan hasil yang sama yaitu Ayemere \& Elijah (2015), Lin et al., (2010), Prastiti \& Meiranto (2013), Klein (2006) dan Sharma et al.,(2009). Independensi merupakan kunci utama yang harus dimiliki oleh komite audit. Tanggung jawabnya dalam mengawasi manajemen memerlukan independensi agar tidak mudah diintervensi oleh pihak lain. Komite audit dengan independensi tinggi cenderung memberikan kepercayaan bagi pihak ekternal mengenai kualitas laporan keuangan yang dihasilkan oleh perusahaan.

Pengujian pada hipotesis keempat diperoleh hasil bahwa ditemukannya pengaruh negative antara hubunganACMEET pada manajemen laba. Dari uji hipotesis dihasilkan nilai koefisien yaitu $-0,004$. Nilai ni memberikan informasi 
mengenai arah dari hubungan antara variabel yang diteliti. Meningkatnya ACMEET akan berdampak pada menurunnya manajemen laba. Tingkat signifikansi yang didapatkan adalah sebesar 0,004maka $\mathrm{H}_{0}$ ditolak. Penelitian sebelumnya yang yang mendapatkan hasil yang sama yaitu penelitian yang dilakukan oleh Marsha \& Ghozali (2017)dan Amalia \& Didik (2017).

Apabila konflik kepentingan yang timbul ketika setiap pihak berusaha untuk mencapai dan mempertahankan tingkat kemakmuran yang dikehendakinya merupakan hal yang memicu terjadinya praktik manajemen laba. Asimetri informasi dapat memberikan kesempatan kepada manajer untuk melakukan perilaku oportunistik (manajemen laba). Apabila informasi akuntansi yang disajikan semakin dimanipulasi oleh manajemen, maka informasi tersebut menjadi tidak relevan. Dengan lebih banyaknya informasi yang dimiliki oleh agent, menjadikan agent termotivasi untuk memenuhi kepentingannya secara sepihak, misalnya CEO baru merekayasa kinerjanya untuk dapat mempertahankan posisinya.

\section{SIMPULAN}

Pengujian pada hipotesis pertama diperoleh hasil bahwa ditemukannya pengaruh negative antara hubungan BCIND pada manajemen laba. Dari uji hipotesis dihasilkan nilai koefisien yaitu $-0,117$. Nilai ni memberikan informasi mengenai arah dari hubungan antara variabel yang diteliti. Meningkatnya BCIND akan berdampak pada menurunnya manajemen laba. Pengujian pada hipotesis kedua diperoleh hasil bahwa ditemukannya pengaruh negative antara hubungan BCMEET pada manajemen laba. Dari uji hipotesis dihasilkan nilai koefisien yaitu $-0,004$. Pengujian pada hipotesis ketiga diperoleh hasil bahwa ditemukannya pengaruh negative antara hubungan ACIND pada manajemen laba. Dari uji hipotesis dihasilkan nilai koefisien yaitu -0,106. Nilai ni memberikan informasi mengenai arah dari hubungan antara variabel yang diteliti. Meningkatnya ACIND akan berdampak pada menurunnya manajemen laba. Tingkat signifikansi yang didapatkan adalah sebesar 0,001dimana nilai ini kurang dari 0,05 yang berarti $\mathrm{H}_{3}$ diterima.Pengujian pada hipotesis keempat diperoleh hasil bahwa ditemukannya pengaruh negative antara hubungan ACMEET pada manajemen laba. Dari uji hipotesis dihasilkan nilai koefisien yaitu -0,004. Nilai ni memberikan informasi mengenai arah dari hubungan antara variabel yang diteliti. Meningkatnya ACMEET akan berdampak pada menurunnya manajemen laba. Tingkat signifikansi yang didapatkan adalah sebesar 0,004maka $\mathrm{H}_{0}$ ditolak.

\section{REFERENSI}

Afnan, A. (2014). Pengaruh Ukuran Dewan komisaris, dan Proporsi Komisaris Independen Terhadap Kinerja Keuangan, dengan Manajemen Laba Sebagai Variabel Intervening. Skripsi. Universitas Diponegoro Semarang.

Amalia, B. Y., \& Didik, M. (2017). Pengaruh Konsentrasi Kepemilikan, Kepemilikan Institusional, Proporsi Dewan Komisaris Independen, dan Frekuensi Rapat Komite Audit Terhadap Praktik Manajemen Laba. Diponogoro Journal of Accounting, 6, 1-14. 
Ayemere, I. L., \& Elijah, A. (2015). Corporate Attributes and Audit Delay in Emerging Markets: Empirical Evidence from Nigeria. International Journal of Business and Social Research, 5(3), 1-10.

Bengtsson, K., Bergstrom, C., \& Nilsson, M. (2006). Earnings Management and CEO Turnovers. Working Paper, School of Economics, Sweden.

Dechow, P. ., Sloan, R. G., \& Sweeney, A. . (1998). Causes and Consequences of Earnings Manipulation: Analysis of Firms Subjects to Enforcement Action by the SEC. Contemporary Accounting Research, 13, 1-36.

Fathoni, \& Ancella. (2013). Pengaruh Efektifitas Dewan Komisaris dan Komite Audit Terhadap Manajemen Laba Untuk Perusahaan Yang Terdaftar Di BEI Tahun 2010 Dan 2011. Fakultas Ekonomi Universitas Indonesia.

Firnanti, F. (2017). Pengaruh Corporate Governance Dan Faktor-Faktor Lainnya, 19(1), 66-80.

Gunawan, I. K., Ari, N., Darmawan, S., \& Purnawati, I. G. A. (2015). Pengaruh Ukuran Perusahaan, Profitabilitas, Dan Leverage Terhadap Manajemen Laba Pada Perusahaan Manufaktur Yang Terdaftar Di Bursa Efek Indonesia (Bei). Journal S1 Ak Universitas Pendidikan Ganesha Jurusan Akuntansi Program S1, 03(01).

Hui, L. J. (2012). Board Monitoring, Management Contracting and Earnings Management: An Evidencefrom ASX Listed Companies. International. International of Economics and Finance, 4(12).

Indriantoro, N., \& Supomo., B. (2014). Metodologi Penelitian Bisnis Untuk Akuntansi $\mathcal{E}$ Manajemen. (1st ed.). Yogyakarta: BPFE.

Klein, A. (2006). Audit Committee, Board of Director Characteristic, and Earnings Management. Law \& Economics. Research Paper Series Working Paper.

Lin, J. W., Mark, I., \& Hwang. (2010). Audit Quality, Corporate Governance, and Earning Management: A Meta-Analysis. International Journal, 21(9), 921-933.

Marsha, \& Ghozali. (2017). Pengaruh Ukuran Komite Audit, Audit Eksternal, Jumlah Rapat Komite Audit, Jumlah Rapat Dewan Komisaris Dan Kepemilikan Institusional Terhadap Manajemen Laba. Diponegoro Journal Of Economics, 6(2).

Nabila, A., \& Daljono. (2013). Pengaruh Proporsi Dewan Komisaris Independen, Komite Audit, Dan Reputasi Auditor Terhadap Manajemen Laba. Journal of Accounting, 2(1), 1-10. https://doi.org/10.1016/j.jmwh.2005.04.004

Narolita, E., \& Krisnadewi, A. (2016). Pengaruh Penerapan Corporate Governance Pada Manajemen Laba Oleh Chief Executive Officer Baru. E Jurnal Akuntansi Universitas Udayana., 14(1), 635-662.

Oktafia, Y. (2017). Pengaruh Good Corporate Governance Terhadap Manajemen Laba. Jurnal Akuntansi.

Perwitasari, D. (2014). Struktur Kepemilikan, Karakteristik Perusahaan, dan manajemen Laba. Jurnal Akuntansi Multiparadigma, 5(3), 432-441.

Prastiti, \& Meiranto, W. (2013). Pengaruh Karakteristik Dewan Komisaris Dan Komite Audit Terhadap Manajemen Laba. Diponegoro Journal Of Accounting, 2(4). 
Puteri, P. A. W. A. (2013). Karakteristik Good Corporate Governance dan Kinerja Perusahaan Manufaktur. E-Jurnal Akuntansi Universitas Udayana, 2(3), 594-613.

Putra, P. A., Sinarwati, N. K., Ari, N., \& Darmawan, S. (2014). Pengaruh Asimetri Informasi dan Ukuran Perusahaan terhadap Praktek Manajemen Laba Pada Perusahaan manufaktur yang terdaftar di Bursa Efek Indonesia. E-Journal S1 Ak Universitas Pendidikan Ganesha, 2(1).

Putra, Putu Adi, Sinarwati, N. K., Ari, N., \& Darmawan, S. (2014). Pengaruh Asimetri Informasi dan Ukuran Perusahaan terhadap Praktek Manajemen Laba Pada Perusahaan manufaktur yang terdaftar di Bursa Efek Indonesia. E-Journal S1 Ak Universitas Pendidikan Ganesha Jurusan Akuntansi Program S1, 2(1).

Scott, W. R. (2014). Financial Accounting Theory (7th ed.). USA.: Pearson Canada Inc.

Sharma, V., Naiker, V., \& Lee, B. (2009). Determinants of Audit Committee Meeting Frequency: Evidence from a Voluntary Governance System. Accounting Horizon, 23(3), 245-263.

Sirait, C., \& Yasa, G. W. (2015). Pengaruh Corporate Governance Terhadap Manajemen Laba Oleh Ceo Baru. E-Journal Akuntansi Universitas Udayana, 10(3).

Sugiyono. (2017). Metode Penelitian Pendidikan Pendekatan Kuantitatif, Kualitatif, dan RED. Bandung: Alfabeta.

Suripto, B. (2012). Pengaruh Karakteristik Dewan Komisaris dan Komite Audit Terhadap Kualitas Laporan Keuangan. Jurnal Akuntansi Dan Manajemen, 23(2), 105-117,.

Watts, R. L., \& Zimmerman, J. L. (1990). Positive Accounting Theory: A Ten Year Perspective. The Accounting Review, 65(1), 131156. 